Print ISSN: 2288-4637 / Online ISSN 2288-4645

doi:10.13106/jafeb.2020.vol7.no9.011

\title{
Factors Affecting Financial Risk: Evidence from Listed Enterprises in Vietnam*
}

\author{
Hang Thu DANG ${ }^{1}$, Duong Thuy PHAN ${ }^{2}$, Ha Thi NGUYEN ${ }^{3}$, Le Hong Thi HOANG ${ }^{4}$
}

Received: July 02, 2020 Revised: July 19, 2020 Accepted: August 10, 2020

\begin{abstract}
This paper analyzes factors affecting enterprise's financial risk listed on the Vietnam stock market. The panel data of research sample includes 524 non-financial listed enterprises on the Vietnam stock market for a period of eleven years, from 2009 to 2019 . The Generalized Least Square (GLS) is employed to address econometric issues and to improve the accuracy of the regression coefficients. In this research, financial risk is measured by the Alexander Bathory model. Debt structure, Solvency, Profitability, Operational ability, Capital structure are independent variables in the study. Firm Size, firm age, growth rate are control variables. The model results show that in order to prevent and limit financial risk for enterprises listed on the Vietnam Stock Market, attention should be paid to variables reflecting Liability structure ratio, Quick Ratio, Return on Assets, Total asset turnover, Accounts receivable turnover, Net assets ratio and Fixed assets ratio. The empirical results show that there are differences in the impact of these factors on the financial risk in state-owned enterprises and non-state enterprises listed on the Vietnam stock market. The findings of this article are useful for business administrators, helping business managers make the right financial decisions to improve the efficiency of financial risk management in enterprises.
\end{abstract}

Keywords: Financial Risk, State-Owned Enterprises, Non-State Enterprises, Vietnam

JEL Classification Code: G30, M40, M41

\section{Introduction}

Risk plays a significant role in almost every single business. Risk is viewed as a necessary evil that should be minimized or mitigated in best possible way. Particularly,

\footnotetext{
*Acknowledgements:

The authors are thankful to University of Transport Technology and Academy of Finance for funding this research. We would like to thank the anonymous referees for their helpful comments and suggestions.

${ }^{1}$ First Author. Lecturer, Faculty of Transport Economics, University of Transport Technology, Vietnam. Email: hangdt@utt.edu.vn

${ }^{2}$ Corresponding Author. Lecturer, Faculty of Transport Economics, University of Transport Technology, Vietnam [Postal Address: 54

Trieu Khuc Road, Thanh Xuan District, Hanoi, 120418, Vietnam] Email: duongpt@utt.edu.vn

${ }^{3}$ Deputy Head, Faculty of Business Finance, Academy of Finance,

Vietnam. Email: nguyenha@hvtc.edu.vn

${ }^{4}$ Dean, Faculty of Transport Economics, University of Transport Technology, Vietnam. Email: lehth@utt.edu.vn

(c) Copyright: The Author(s)

This is an Open Access article distributed under the terms of the Creative Commons Attribution Non-Commercial License (https://creativecommons.org/licenses/by-nc/4.0/) which permits unrestricted non-commercial use, distribution, and reproduction in any medium, provided the original work is properly cited.
}

in a globalized world, it becomes increasingly important to identify, manage, and explore risk across organizations to accomplish business success and longevity (Rahmi, Azma, Muttaqin, Jazil, \& Rahman, 2016). Financial risk is one of the major concerns of every business across fields and geographies. According to Eichhorn (2004) and Napp (2011), financial risk can take two different forms. Financial risk due to objective factors depend on changes in financial markets such as interest rates, market rates and commodity prices. Financial risk can also be due to subjective factors, in which the financial situation is the source of risks. Financial risk not only affect the performance, balance of cash flow and solvency, but also affect the firm value of enterprises.

The study of factors affecting the financial risk of enterprises is carried out in many different countries such as China, India, Taiwan ... Alexander Bathory's research has provided a model to measure financial risk in enterprises in 1984. Studies applying Alexander Bathory's model can include: Bhunia and Mukhuti (2012) studying financial risk based on secondary data collected from financial reports of 513 enterprises listed at Bombay Stock Exchange, India for the period 2010-2011; Gang \& Dan (2012) studied financial risk using financial statements data of 216 listed enterprises 
at Shenzhen Stock Exchange, China in 2010; Simantinee and Kumar (2015) measurement and identified factors affecting financial risk of 50 enterprises including banks, analytical data collected from financial statements of 41 enterprises listed on NIGTY stock exchange from 2014 - 2015; Cao and Zen (2005) studied the factors affecting the financial risk of listed enterprises in China; Zhou and Zhao (2006) studied the financial risk of private enterprises in China.

Currently, Vietnam is becoming more and more integrated into the world economy. The volatility of the business environment and the inevitable contradictions arising in the growth process require Vietnamese businesses to increasingly focus on risk management. The Vietnamese government still holds a large portion of ownership in former state-owned economic enterprises / state corporations as well as enterprises in strategic areas, such as mining, quarrying, and electricity, oil and gas. In addition, there are many studies showing the differences between stateowned and private enterprises. According to Nguyen and Nguyen (2020) state-owned enterprises have a negative impact on sustainable disclosure. According to Nguyen and Nguyen (2020) the negative impact of capital structure on the performance of state-owned enterprises is stronger than that of private enterprises. This practice raises questions about the influence of state ownership on the operation of enterprises and financial risk in the Vietnamese context.

This paper provides empirical evidence of factors affecting financial risk in listed enterprises in Vietnam on the period 2009-2019. The results of the study will be useful to corporate executives and policy makers in financial risk management.

\section{Literature Review and Hypotheses}

\subsection{Literature Review}

Researcher Alexander Bathory proposed a model to measure the financial risk of businesses in 1984 with scales belonging to five groups of financial indicators such as capital structure, profitability, and proportion of capital. invest in assets ... and five financial indicators to identify financial risk. Bathory's model suggests that the higher the value of $\mathrm{FR}_{\mathrm{it}}$, the better the financial position of the company and the lower the financial risk.

Cao and Zen (2005) use the coefficient of financial leverage as a dependent variable to study the financial risk of large enterprises. Research results have shown that financial risk is positively correlated with debt size and structure, negatively correlated with performance and profitability, and no correlation with interest rates and solvency. Gang and Dan (2012), Bhunia and Mukhuti (2012) show that financial risk are significantly correlated with the current solvency ratio (CR), profitability ratio of revenue (ROS), fixed capital (FAR), self-financing (NAR); low correlation with the turnover of fixed assets (FAT) of total assets turnover (TAT); and there is no correlation with debt structure (CL / NCL), inventory turnover (IT), receivables turnover (ART).

Zhou and Zhao (2006) adopted the Z model and found that the average level of financial risk of privately owned listed enterprises is significantly higher than that of stateowned listed enterprises. Simantinee and Kumar (2015) used the Alexander Bathory model to measure financial risk and regression analysis used to study the relationship between financial risk and factors affecting financial risk. The research results show that: (i) fixed asset turnover (FATR) has the greatest positive correlation with financial risk; (ii) the ratio of fast solvency $(\mathrm{QR})$ has the greatest negative correlation to financial risk; (iii) financial risk positively correlated with earnings per share (DPS), net profit margin (OPM), net profit margin (NPM), current solvency ratio (CR), financial coverage ratio (FCCRPT) and fixed asset turnover (FATR); (iv) financial risk is inversely correlated with net profit per share (NOPS), return on long-term capital (ROLF), quick solvency ratio $(\mathrm{QR})$ and ability ratio interest payment (ICR); (v) financial risk is not correlated with inventory turnover (ITR) and total asset turnover (TATR).

The study on this issue in Vietnam has been verified by Hau (2017) when analyzing the factors affecting the financial risk of 34 real estate listed enterprises on HSX in the period 2013 - 2015. The research show that the financial risk of real estate listed enterprises in Ho Chi Minh Stock Market have a significant correlation with the liquidity ratio, current payment, quick solvency, general solvency, fixed capital; and there is no correlation with debt structure, revenue-yield ratios, profitability ratios of assets, inventory turnover, fixed assets turnover, total assets turnover, accounts receivable turnover revenues, self-financing.

The Alexander Bathory model was used as a dependent variable in empirical studies in India, China, Taiwan ... through a secondary database collected at Stock Exchanges with all different types of businesses, production and business lines. In Vietnam, research on financial risk is quite large, but applying this theoretical model to verify with the database of enterprises listed on the stock market, especially with the ratio of state-owned, explaining research results and presenting recommendations are not yet available. Therefore, within the scope of the study, the Alexander Bathory model continues to be tested in Vietnam to identify factors affecting financial risk, thereby contributing to improving the efficiency of financial risk management of enterprises.

\subsection{Research Hypotheses}

Based on the theoretical and empirical research on financial risk, the authors set up 5 research hypotheses on 
the factors affecting the financial risk of enterprises listed on the Vietnam stock market is as follows:

Debt structure: The debt structure of the enterprise indicates the proportion of short-term debt to total liabilities. If the enterprise uses too much short-term debt, it will put pressure on the company to pay its due debts, leading to the risk of financial risk. The results of Bathory's study proved that debt structure is not correlated with financial risk. This result is also proved by the research of Gang and Dan (2012), Bhunia and Mukhuti (2012), and Hau (2017). In the case of firms listed on Vietnam's stock market, how is financial risk and debt structure related? This question brings puts the authors to formulate the first hypothesis:

$\boldsymbol{H}_{\mathbf{1}}:$ Debt structure of industry listed firms is positively correlated with financial risk.

Solvency: The solvency shows quite clearly the financial situation of the business. Solvency means the ability to pay its due debts at any time (principal and interest). Good financial situation, high solvency will meet due debts and low financial risk. In Bathory's model, financial risk is negatively related to solvency. This result has been proved through the results of the research: Gang and Dan (2012), Bhunia and Mukhuti (2012), and Hau (2017). From the above arguments, the hypothesis of the correlation between the solvency and financial risk is:

$\boldsymbol{H}_{2}$ : The solvency of listed enterprises in industry is negatively correlated with financial risk.

Profitability: Profitability reflects the ability to generate profit of a unit of cost or input or output that reflects the business results. When the business activities of industrial enterprises are favorable, creating conditions for increasing profits, the profitability of enterprises also increases. Businesses have the opportunity to increase accumulated profits, improve solvency, cover due debts, and reduce financial risk. Studies have shown an inverse relationship between financial risk and profitability: Gang and Dan (2012), and Bhunia and Mukhuti (2012). However, the results of Hau (2017) do not confirm this assumption. The hypothesis is given that:

$\boldsymbol{H}_{3}:$ Profitability of listed enterprises is negatively correlated with financial risk.

Operation ability: Operational efficiency is the ability to achieve operational results when consuming the inputs in the business process of industrial enterprises. The growth of turnover or payment speed shows the development of business operations of enterprises, the risk of financial risk is low and vice versa. The results of Bathory and subsequent studies do not prove the relationship of performance to financial risk (Gang \& Dan, 2012; Bhunia \& Mukhuti, 2012; Hau, 2017). The hypothesis is given that:

$\boldsymbol{H}_{4}:$ Operation ability of listed enterprises is negatively correlated with financial risk.

Capital structure: The capital structure represents the proportion of each type of capital in the total capital. When the high self-financing ratio is equivalent to the ratio of debt to total capital resources, the company's ability to pay debts is easily guaranteed and creditors will be safer, financial risk of the company. will fall. The higher the value of the fixed assets, the more the lenders' debts are guaranteed, the financial risk of the business will decrease and vice versa. The results of Bathory's research and subsequent studies show that there is an inverse relationship between financial risk and capital structure (Gang \& Dan, 2012; Bhunia \& Mukhuti, 2012; Hau, 2017). The hypothesis is as follows:

$\boldsymbol{H}_{5}:$ The capital structure of industry listed firms is negatively correlated with financial risk.

\section{Research Methods}

\subsection{Research Model}

The concept of analysis of the factors that influence financial risk is explained by the following framework (Figure 1)

\section{Dependent variable:}

From the previous research, methods of measuring financial risk include the asset-liability ratio, probabilistic analysis, financial leverage coefficient, etc. Financial risk measured by asset -liability ratio method is vague, and it still needs to combine with return on assets. In this paper, Alexander Bathory model was used to measure the financial risk. The model can be expressed as below:

$$
F R_{i t}=S Z L_{i t}+S Y_{i t}+G L_{i t}+Y F_{i t}+Y Z_{i t}
$$

$\mathrm{FR}_{\mathrm{it}}$ is the value measuring financial risk of index, We took it as dependent variable in this paper.

$\mathrm{SZL}_{\mathrm{it}}=$ (profit before tax + depreciation + deferred tax $) /$ current liabilities

$\mathrm{SY}_{\text {it }}=$ Pre-tax profit/operating capital.

$\mathrm{GL}_{\mathrm{it}}=$ Shareholders' interests / current liabilities

$\mathrm{YF}_{\mathrm{it}}=$ Net tangible assets / total liabilities

$\mathrm{YZ}_{\mathrm{it}}=$ Working capital / total assets.

According to Alexander Bathory's view, the smaller the value of $\mathrm{FR}_{\text {it }}$ it is, the weaker the enterprise strength is, and the higher financial risk of enterprise is. 


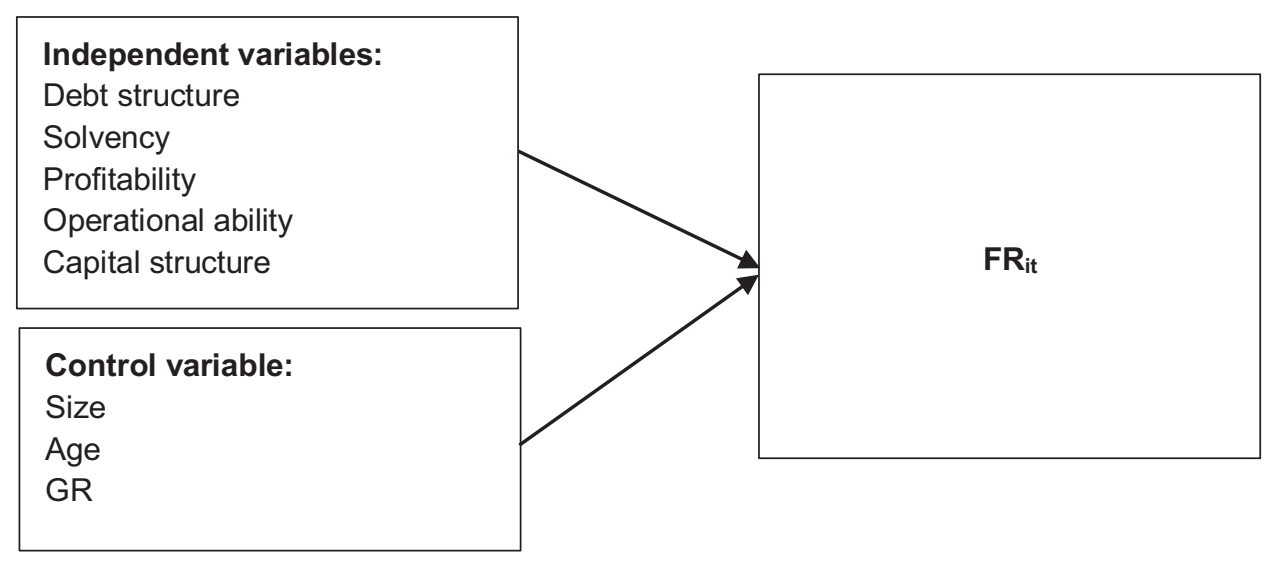

Figure 1: Research model of factors affecting enterprises' financial risk

Table 1: Description of variables in the research model

\begin{tabular}{|c|c|c|c|c|}
\hline Variable name & Code & Related definition & Notes & Expectations \\
\hline Financial risk & $\mathrm{FR}_{\text {it }}$ & Bathory's model metrics & Financial risk metric values & \\
\hline Debt structure & DS & Liability structure ratio & Current liabilities / non-current liabilities & + \\
\hline Solvency & QR & Quick Ratio & (Current assets-inventory)/ current liabilities & - \\
\hline \multirow{2}{*}{ Profitability } & $\mathrm{ROA}$ & Return on Assets & $\mathrm{ROA}=$ Net income $/$ Average total assets & \multirow[b]{2}{*}{-} \\
\hline & ROS & Return on Sales & ROS $=$ Net income $/$ Sales & \\
\hline \multirow{4}{*}{ Operation ability } & IT & Inventory turnover & Cost of goods sold/inventories & \multirow{4}{*}{ - } \\
\hline & FAT & Fixed asset turnover & Sales/net fixed assets & \\
\hline & TAT & Total asset turnover & Sales/total assets & \\
\hline & RT & $\begin{array}{l}\text { Accounts receivable } \\
\text { turnover }\end{array}$ & Annual credit sales/accounts receivable & \\
\hline \multirow{2}{*}{ Capital structure } & ES & Net assets ratio & Equity/total assets & \multirow{2}{*}{ - } \\
\hline & FAS & Fixed assets ratio & Fixed assets/total assets & \\
\hline Sale Growth & GR & Sale Growth & $\begin{array}{l}\text { (Current period net sales - previous period } \\
\text { net sales)/ previous period net sales }\end{array}$ & \\
\hline Firm size & SIZE & Firm size & Firm size measured by log of total assets & \\
\hline Firm age & AGE & Firm age & Year of research - year of establishment & \\
\hline
\end{tabular}

\section{Independent variables:}

Cao and Zen (2005) employed liabilities scale, interest rate, debt structure, profitability, operation ability and solvency as the factors. Wang and Chen (2010) selected solvency, profitability and operation management to investigate financial risk and the financing of firms. In this study, we summarized in five main factors that affect construction firm's financial risk, which are debt structure, solvency, profitability, operation ability, and capital structure, set 10 indexes as independent variables to express the five main factors. Controlled variables are sale growth, firm size and firm age. The detail is shown in Table 1.

\subsection{Research Data}

The study used panel data collected from 524 nonfinancial enterprises listed on Vietnam Stock Market over an eleven years period, from 2009 to 2019, provided by FiinGroup JSC. Research data is extracted from the audited financial statements of these enterprises. The sample includes 279 state-owned enterprises and 245 non-state enterprises. 


\subsection{Research Method}

The baseline analysis was first performed to screen the sample, to eliminate observations that were too large, too small, or too different from the sample size. This basic analysis step helps to check the suitability of the sample before performing regression analysis OLS, FEM, REM, to ensure the reliability of quantitative research results. Specifically, the author group conduct statistical description analysis, correlation analysis to eliminate multi-collinear phenomena between independent variables. After selecting the appropriate method to run the model, the author examine the variance of variance, multicollinearity, autocorrelation, endogeneity of the model. In case the model has a defect, the author will use the GLS (Generalized least squares) method to overcome.

\section{Empirical Results}

The empirical results of factors affecting financial risk in state owned enterprises are shown in Table 2. We compare and choose which model is suitable model is FEM or REM. To consider and select the appropriate model between the two regression methods, the author uses the Hausman test. Multicollinearity test results show that the magnification coefficient of VIF variance are $<10$, the model has no multicollinearity phenomenon. The mean VIF is 1.31 , which indicates that the possibility of multicollinearity is not significant. The White test indicates that the model has heterogeneity ( $\mathrm{p}$-value $<5 \%$ ) and the Breusch and Pagan Lagrangian Multiplier test for random effects results (Table 2) rejected the null hypothesis that the Pooled OLS model was appropriate. Following the results from the Hausman test $(\mathrm{P}$-value $=0.0000<0.05)$, selecting the appropriate model is FEM, the author proceeds to overcome the discovered defects of the model by GLS method.

The empirical results of factors affecting financial risk in non state owned enterprises are shown in Table 3. As the results of regression analysis show that the value of VIF coefficient is less than 10 , there is multi-collinear phenomenon. The maximum VIF is 1.72 , which indicates that the possibility of multicollinearity is not significant.

Table 2: Regression results of State-owned enterprises

\begin{tabular}{|c|c|c|c|c|}
\hline \multirow{2}{*}{ Variable } & \multirow{2}{*}{ VIF } & \multicolumn{3}{|c|}{ Regression coefficients } \\
\hline & & POLS & FEM & REM \\
\hline DS & 1.00 & $5.76 e-09$ & $3.69 e-09$ & $4.31 e-09$ \\
\hline QR & 1.69 & $2.451^{* * *}$ & $2.340^{* * *}$ & $2.366^{* * *}$ \\
\hline ROS & 1.47 & 0.0768 & -0.180 & -0.183 \\
\hline ROA & 1.55 & 1.073 & -0.976 & -0.0530 \\
\hline IT & 1.01 & -0.000000297 & $7.15 e-09$ & $-9.28 e-09$ \\
\hline FAT & 1.06 & $0.000695^{*}$ & 0.000133 & 0.000218 \\
\hline TAT & 1.57 & $-0.439^{* * *}$ & $-0.227^{* *}$ & $-0.344^{* \star *}$ \\
\hline RT & 1.51 & $0.0301^{* * *}$ & $0.0258^{* * *}$ & $0.0253^{* * *}$ \\
\hline ES & 1.88 & $11.39^{* * *}$ & $13.85^{\star * *}$ & $12.98^{* * *}$ \\
\hline FAS & 1.10 & $5.187^{* * *}$ & $2.834^{* * *}$ & $3.764^{* * *}$ \\
\hline AGE & 1.03 & -0.00316 & $-0.0422^{* *}$ & -0.00691 \\
\hline SIZE & 1.18 & $0.148^{* * *}$ & $0.944^{* * *}$ & $0.384^{* * *}$ \\
\hline GR & 1.01 & 0.00333 & 0.00472 & 0.00608 \\
\hline Cons & & $-6.715^{\star * *}$ & $-28.30^{* * *}$ & $-13.24^{* * *}$ \\
\hline $\mathrm{N}$ & & 2605 & 2605 & 2605 \\
\hline R-sq & & 0.828 & 0.800 & \\
\hline Significance & & $F(13,2591)=959.98$ & $F(13,2312)=709.88$ & Wald chi2(13) = 10473.02 \\
\hline White test & & Chi2 $(104)=1068.29$ & Prob $>$ Chi2 $=0.0000$ & \\
\hline LM test & & Chibar2(01) = 1718.96 & Prob $>$ chibar2 $=0.0000$ & \\
\hline Hausman test & & Chi2(11) $=45.85$ & Prob $>$ chi2 $=0.0000$ & \\
\hline Wooldridge test & & $F(1,273)=15.293$ & Prob > F = 0.001 & \\
\hline
\end{tabular}

Note: $\left({ }^{*}\right),\left(^{* *}\right),\left(^{* * *}\right)$ represent for the significant level at $1 \%, 5 \%$ and $10 \%$, respectively 
Table 3: Regression results of non-state-owned enterprises

\begin{tabular}{|c|c|c|c|c|}
\hline \multirow{2}{*}{ Variable } & \multirow{2}{*}{ VIF } & \multicolumn{3}{|c|}{ Regression coefficients } \\
\hline & & POLS & FEM & REM \\
\hline DS & 1.01 & -0.0000406 & 0.0000337 & 0.0000183 \\
\hline QR & 1.34 & $2.599^{* * *}$ & $2.579^{* * *}$ & $2.572^{* * *}$ \\
\hline ROS & 1.03 & 0.0166 & -0.0321 & -0.0227 \\
\hline ROA & 1.28 & -0.510 & -0.980 & -0.166 \\
\hline IT & 1.02 & $-0.0000499^{* * *}$ & $-0.0000441^{* * *}$ & $-0.0000441^{* * *}$ \\
\hline FAT & 1.05 & 0.000190 & 0.000550 & 0.000238 \\
\hline TAT & 1.72 & $-0.539^{* * *}$ & $-1.115^{\star * *}$ & $-0.854^{* * *}$ \\
\hline RT & 1.54 & $0.0372^{\star \star \star}$ & 0.0187 & $0.0258^{\star \star}$ \\
\hline ES & 1.52 & $13.03^{* * *}$ & $15.79^{* * *}$ & $14.88^{* * *}$ \\
\hline FAS & 1.11 & $5.348^{* * *}$ & $3.538^{* * *}$ & $4.125^{* * *}$ \\
\hline AGE & 1.03 & -0.0193 & $-0.106^{* * *}$ & $-0.0479^{*}$ \\
\hline SIZE & 1.24 & $-0.167^{\star \star}$ & 0.174 & -0.0871 \\
\hline GR & 1.01 & -0.000688 & 0.00105 & 0.000564 \\
\hline Cons & & 1.179 & -7.204 & -0.853 \\
\hline $\mathrm{N}$ & & 2379 & 2379 & 2379 \\
\hline R-sq & & 0.729 & 0.609 & \\
\hline Significance & & $F(13,2365)=489.60$ & $F(13,2117)=253.38$ & Wald chi2 $2(13)=4175.97$ \\
\hline White test & & Chi2 $(103)=620.34$ & Prob $>$ Chi2 $=0.0000$ & \\
\hline LM test & & Chibar2(01) $=915.46$ & Prob $>$ chibar2 $=0.0000$ & \\
\hline Hausman test & & Chi2 $(12)=13.53$ & Prob $>$ chi2 $=0.2601$ & \\
\hline Wooldridge test & & $F(1,240)=4.856$ & Prob $>F=0.285$ & \\
\hline
\end{tabular}

Note: $\left({ }^{*}\right),\left({ }^{* *}\right),\left({ }^{* *}\right)$ represent for the significant level at $1 \%, 5 \%$ and $10 \%$, respectively

The White test indicates that the model has heterogeneity (p-value $<5 \%$ ) and the Breusch and Pagan Lagrangian Multiplier test for random effects results (Table 3) rejected the null hypothesis that the Pooled OLS model was appropriate. Following the results from the Hausman test $(\mathrm{P}$-value $=0.2601>0.05)$, selecting the appropriate model is REM, the author proceeds to overcome the discovered defects of the model by GLS method.

The regression coefficient obtained by the GLS regression method shows that, in state-owned enterprises, the $\mathrm{FR}_{\mathrm{it}}$ is positively related to the DS (shown in the regression coefficients received negative values are $9.39 \mathrm{e}-09$. In nonstate enterprises, DS is no correlation with $\mathrm{FR}_{\mathrm{it}}$.

The regression results (Table 4) show that, in state owned enterprises, the relationship between TAT and $\mathrm{FR}_{\mathrm{it}}$ is in the opposite direction (the regression coefficient receives negative values is -0.1513 ), this relationship is statistically significant ( $p$-value $<0.01$ ). The relationship between
QR, ROA, RT, ES, FAS and SIZE with $\mathrm{FR}_{\text {it }}$ is in the same direction (the regression coefficient receives negative values is $2.0846,1.8659,0.0152,8.6500,2.6590$ and 0.1339 , this relationship is statistically significant (p-value $<0.01$ ). In addition, no statistically significant relationship was found between ROS, IT, FAT, AGE and GR with $\mathrm{FR}_{\mathrm{it}}$ in state owned enterprises.

Besides, in non-state enterprises, the relationship between IT, TAT and SIZE with $\mathrm{FR}_{\mathrm{it}}$ is in the negatively (the regression coefficient receives negative values is $-0.0003,-0.3381$ and -0.1426 ), this relationship is statistically significant ( $\mathrm{p}$-value $<0.01$ ). In addition, the relationship between QR, ROA, RT, ES and FAS with $\mathrm{FR}_{\mathrm{it}}$ is in the positively (the regression coefficient receives negative values is $1.9681,2.7645$, $0.0199,8.7263,2.3989)$, this relationship is statistically significant ( $p$-value $<0.01$ ). Moreover, no statistically significant relationship was found between DS, ROS, FAT, AGE and GR with $\mathrm{FR}_{\mathrm{it}}$ in non-state owned enterprises. 
Table 4: GLS regression results of model

\begin{tabular}{|l|c|c|}
\hline Variable & $\begin{array}{c}\text { State-owned } \\
\text { enterprises }\end{array}$ & $\begin{array}{c}\text { Non state-owned } \\
\text { enterprises }\end{array}$ \\
\hline DS & $9.39 \mathrm{e}-09^{* * *}$ & $1.65 \mathrm{e}-06$ \\
\hline QR & $2.0846^{* * *}$ & $1.9681^{* * *}$ \\
\hline ROS & -0.0468 & 0.0062 \\
\hline ROA & $1.8659^{* * *}$ & $2.7645^{* * *}$ \\
\hline IT & $-2.26 \mathrm{e}-09$ & $-0.0003^{* * *}$ \\
\hline FAT & 0.0002 & -0.0003 \\
\hline TAT & $-0.1513^{* * *}$ & $-0.3381^{* * *}$ \\
\hline RT & $0.0152^{* * *}$ & $0.0199^{* * *}$ \\
\hline ES & $8.6500^{* * *}$ & $8.7263^{* * *}$ \\
\hline FAS & $2.6590^{* * *}$ & $2.3989^{* * *}$ \\
\hline AGE & -0.0064 & 0.0017 \\
\hline SIZE & $0.1139^{* * *}$ & $-0.1426^{* * *}$ \\
\hline GR & 0.0037 & -0.0001 \\
\hline Cons & $-4.2281^{* * *}$ & $2.749^{* * *}$ \\
\hline
\end{tabular}

Note: $\left.\left({ }^{*}\right),\left({ }^{* *}\right),{ }^{* * *}\right)$ represent for the significant level at $1 \%, 5 \%$ and $10 \%$, respectively

\section{Discussion and Recommendations}

\subsection{Discussion}

Firstly, the impact of debt structure on financial risk. For state-owned enterprises, the debt structure has a positive impact on $\mathrm{Fr}_{\mathrm{it}}$, the opposite direction to financial risk. Whereas, non-state enterprises, there was no relationship between debt structure and financial risk, this result is consistent with the research results of Gang and Dan (2012), Bhunia and Mukhuti (2012), and Hau (2017).

Secondly, the impact of solvency on financial risk. The solvency affects positively on $\mathrm{Fr}_{\mathrm{it}}$, the opposite of financial risk, the higher the solvency of enterprises, the lower the financial risk. This effect is greater in non-State enterprises and less in SOEs. This result is consistent with the results of the research: Gang and Dan (2012), Bhunia and Mukhuti (2012), and Hau (2017).

Third, the impact of profitability on financial risk. ROA positively affects $\mathrm{Fr}$, profitability is inversely correlated with financial risk. This effect is greater in SOEs and less in nonState enterprises. This result is consistent with the results of the research: Gang and Dan (2012), and Bhunia and Mukhuti (2012).

Fourth, the impact of performance on financial risk. Total asset turnover is positively correlated with low-impact financial risk in both SOEs and non-State enterprises, the impact of asset turnover in private enterprises is almost negligible. While receivables turnover has a negative correlation with financial risk. This effect is greater in nonState enterprises and less in SOEs. In addition, the inventory turnover of private enterprises is negatively related to financial risk with negligible impact. This result is contrary to the results of Gang and Dan (2012), Bhunia and Mukhuti (2012), and Hau (2017).

Fifth, the impact of capital structure on financial risk. Capital structure has a negative impact on financial risk with a significant impact on both state-owned and private enterprises, especially the impact of the self-financing factor on financial risk. This result is consistent with the research results of Gang and Dan (2012), Bhunia and Mukhuti (2012), and Hau (2017).

\subsection{Recommendations}

The model results show that in order to prevent and limit financial risk for enterprises listed on the Vietnam Stock Market, attention should be paid to variables reflecting debt structure (DS) and solvency (QR), profitability (ROA), performance (TAT, RT), capital structure (ES, FAS). Some recommendations for independent variables to increase the value of $\mathrm{Fr}_{\text {it }}$ and reduce financial risk are as follows:

Building a reasonable capital structure: The results of the study show that the higher the ratio of equity to total capital (ES), the higher the value of $\mathrm{Fr}_{\text {it }}$ and the lower the financial risk. Therefore, enterprises need to rebuild capital structure in the direction of increasing the proportion of equity in total capital and mobilizing capital from many other sources. In addition, businesses need to improve the use efficiency of fixed assets, which helps businesses take the initiative in expanding the scale of operations, investment, and technological innovation.

Improving solvency: Solvency in enterprises has a negative relationship with financial risk. In order to minimize financial risk, businesses need to improve their ability to pay short-term debts by flexibly applying various solutions such as increasing the liquidity of assets, building a reasonable debt structure.

Improving profitability: According to the research results, profitability is negatively correlated with financial risk, especially the ROA is statistically significant $0.00 \%$, meaning that the more ROA the higher the financial risk, the lower is and vice versa. In order to improve profitability, businesses need to improve their competitiveness to increase sales revenue and have good cost control measures.

Improving operational efficiency: According to the regression of performance research (expressed by RT indicator) have a negative impact on the financial risk of businesses. This shows that, when business executives enhance the management of receivables, increase the amount of money collection, minimize the short-term capital 
occupied by customers, it is also a good control measure. financial risk of the business.

\section{Conclusion}

In summary, through a set of data collected from 279 state enterprises and 245 non-state listed enterprises, the authors analyzed the impact of factors on the financial risk of the two groups of enterprises. Empirical results from the GLS regression show that the increase in solvency, profitability, accounts receivable turnover, and capital structure have a negative correlation to the financial risk of both types of SOEs and non-State enterprises. In addition, debt structure has an inverse relationship with the financial risk of stateowned enterprises, inventory turnover has a positive relationship with the financial risk of private enterprises with the degree of impact negligible dynamic. The research results of this article are useful for business administrators, helping business managers make the right financial decisions to improve the efficiency of financial risk management in enterprises.

\section{References}

Bathory, A. (1984). Predicting Corporate Collapse: Credit Analysis in the Determination and Forecasting of Insolvent Companies. London, UK: Financial Times Business Information.

Bhunia, A., \& Mukhuti, S. (2012). Financial risk measurement of small and medium-sized companies listed in Bombay Stock Exchange. International Journal of Advances in Management and Economics, 1(3), 27-34. DOI: 10.31270/ ijame/01/03/2012/04

Cao, D., \& Zen, M. (2005). An Empirical Analysis of Factors Influencing Financial Risk of Listed Companies in China. Techno Economics \& Management Research, 6, 37-38.
Eichhorn, F. J. (2004). Financial risk management in German SME findings of a qualitative market research study. Zeitschrift für das Gesamte Kreditwesen, 57, 828-832.

Gang, F., \& Liu, D. (2012). Empirical study on the financial risk factors for small and medium-sized enterprise: The evidence from 216 companies of small plates stock market in China. Journal of Contemporary Research in Business, 3(9), 380-387.

Hau, V. T. (2017). An analysis of factors influencing financial risk of real estimate firms listed on Ho Chi Minh stock market. Journal of Economics and Development, 240, 86-93.

Napp, A. K. (2011). Financial Risk Management in SME: The Use of Financial Analysis for Identifying, Analyzing and Monitoring. Aarhus, Denmark: Aarhus University.

Nguyen, A. H., \& Nguyen, L. H. (2020). Determinants of Sustainability Disclosure: Empirical Evidence from Vietnam. Journal of Asian Finance, Economics, and Business, 7(6), 73-84. https://doi.org/10.13106/jafeb.2020.vol7.no6.073

Nguyen, H. T., \& Nguyen, A. H. (2020). The Impact of Capital Structure on Firm Performance: Evidence from Vietnam. Journal of Asian Finance, Economics, and Business, 7(4), 97-105. https://doi.org/10.13106/jafeb.2020.vol7.no4.97

Rahmi, M., Azma, N., Muttaqin, A. A., Jazil, T., \& Rahman, M. (2016). Risk Volatility Measurement: Evidence from Indonesian Stock Market. Journal of Asian Finance, Economics and Business, 3(3), 57-65. https://doi.org/10.13106/jafeb.2016. vol3.no3.57.

Simantinee, S., \& Kumar, T. V. V. (2015). Factors Influencing Financial Risk-A Case Study of NSE NIFTY Companies. International Journal in Management \& Social Science, 3(8), 132-137.

Wang, J., \& Chen, Z. (2010). Financing Constraints, Financial Risk and Empirical Study on the Growth of SMEs. Seeker Journal, 9, 15-18.

Zhou, C., \& Zhao, D. (2006). Empirical Research on Financial Risks of China's Private Enterprises. Soft Science of China, 45-51. 